\title{
Geothermal Energy Potential of Pakistan on the Basis of Abandoned Oil and Gas wells
}

\author{
Asif Mehmood*, Jun Yao, Dong Yan Fun and Atif Zafar \\ China University of Petroleum, East China
}

\begin{abstract}
In Pakistan, round about 1000 oil and Gas exploratory wells have been drilled having depth ranging from $230 \mathrm{~m}$ to $+6400 \mathrm{~m}$. More than 60 percent wells have been abandoned or dry wells. In spite of all exploratory effort we are not able to overcome the energy need of the country. Present study looks forward to reutilizing these abandoned wells by using subsurface data related to thermal characteristics of rock sequence. Present study shows heartening geothermal gradient exception in lower Indus Basin coupled with buried fossil-fail-rift basement structure. Aeromagnetic survey has also disclosed significant prediction for the "hot dry rock" geothermal energy in KharanPanjgur tectonic depression in western part of the Pakistan. Literature review shows for electricity production hot dry rock (HDR) geothermal environment offers massive potential. These resources are mostly much deeper than the hydrothermal resources. Hot dry rock energy comes from moderately water-free hot rock found at a depth of 4,000 meters or more below the earth surface. In contrast to a geothermal field in one of the tectonic/volcanic anomalies, the HDR system depends on the artificial simulation of tight formations by hydraulic fracturing to create underground heat exchanger. Fluid circulated in closed circuit mode where as reservoir pressure is managed by balanced production and injection rates in multiple well arrays. Current study shows the matchless application of collection data of Oil and Gas exploratory wells to develop renewable and sustainable energy operation in Pakistan.
\end{abstract}

Keywords: Energy; Environment; Reservoirs; Coal; Hydrocarbon; Exploration; Gas wells

\section{Introduction}

The basic study from which this paper is arranged is the result of swiftly depleting petroleum reserves and increasing need throughout the world for rising quantities of energy in all forms. Based on the present increasing trends of the world's population and energy demands, it is expected that the conventional sources (Oil, Gas and Coal) for the energy generation will be exhausted by the end of present century (Figure 1) similar condition are emerging in Pakistan. According to the research report of Tariq based on information of Ministry of Petroleum and Natural Resources, Pakistan is suffer energy crises from 2014 to 2025 because 10 of the largest Oil and Gas reservoirs of the country will be exhausted during 2014-2025. Because of too much consumption of fusel fuels in Pakistan danger of energy crises is constantly increasing.

Continuously efforts are being made to advance the renewable energy technology (particularly the hydel, solar, wind, biomass) for the discovery of effective energy-generation sources, minimizing environment risk and lowering production cost. In addition to these sources, the geothermal energy sources should also be given payable interest. As of 2000, approximately 8,000 megawatts (MW) of geothermal electrician generation capacity was present in more than 20 countries, mainly in United State, Philippines, Italy, Mexico, and Indonesia [1]. There is an evaluation $15,000 \mathrm{MW}$ of generation capacity in geothermal resources worldwide in 2008 and more than 46 countries were producing power from geothermal energy [2]. An estimation of the installed thermal power for direct utilization at the end of 2014 was $70,885 \mathrm{MWt}$ approximately 2218 well were drilled in 42 countries and US $\$ 20$ billion invested in projects by 49 countries [3]. Geothermal energy is used directly for the variety of purposes, space heating, snow melting, green house production and more (Table 1).

Considering the geodynamic scenario, enormous geothermal energy potential exists in Pakistan. For the generation of geothermal energy generally, the flood-plain regions are not encouraging but the present study of preliminary anticipated thermal gradients in the lower Indus plains show interesting abnormal conditions revealing new geothermal source potentials associated with the relatively deeper "Hot Dry Rocks".

Current study describes the background of the "Hot Dry Rocks" as the exploitable renewable geothermal energy source, the relevant technology, the hot dry rock in Pakistan and possible employment of the data of the exploratory Oil and Gas wells to discover the potential targets for the comprehensive study to be required for designing the electric power generation options.

\section{Hot Dry Rock Geothermal Energy}

It seems very simple that from the heat of earth's core geothermal energy is derived and this energy clean, renewable and reliable. If properly developed, it can offer a sustainable, $\mathrm{CO}_{2}$-free and independent of time and metrological conditions. In the upper portion of the earth there are distinct variations in the distribution patterns of geothermal heat flow. Thus, the exploration and subsequent development of geothermal energy is difficult task without its sufficient understanding nothing could successfully be achieved. Basically, the understanding about geothermal energy begins with the understanding of the source of this energy the earth's internal heat. The Earth's temperature increases with depth (Figures $2 a$ and $2 b$ ), at the center the temperature is more than $5000^{\circ} \mathrm{C}$. A portion of heat is generated by the constantly

"Corresponding author: Asif Mehmood, China University of Petroleum, China Tel: +8613156879650; E-mail: asifupc@yahoo.com

Received June 08, 2017; Accepted June 25, 2017; Published June 30, 2017

Citation: Mehmood A, Yao J, Fun DY, Zafar A (2017) Geothermal Energy Potential of Pakistan on the Basis of Abandoned Oil and Gas wells. J Pet Environ Biotechno 7: 332. doi: 10.4172/2157-7463.1000332

Copyright: () 2017 Mehmood A, et al. This is an open-access article distributed under the terms of the Creative Commons Attribution License, which permits unrestricted use, distribution, and reproduction in any medium, provided the original author and source are credited. 
Citation: Mehmood A, Yao J, Fun DY, Zafar A (2017) Geothermal Energy Potential of Pakistan on the Basis of Abandoned Oil and Gas wells. J Pet Environ Biotechnol 7: 332. doi: 10.4172/2157-7463.1000332

Vorld Primary Energy Consumption Million Metric Tons of Oil Equivalent, 1950-2050)

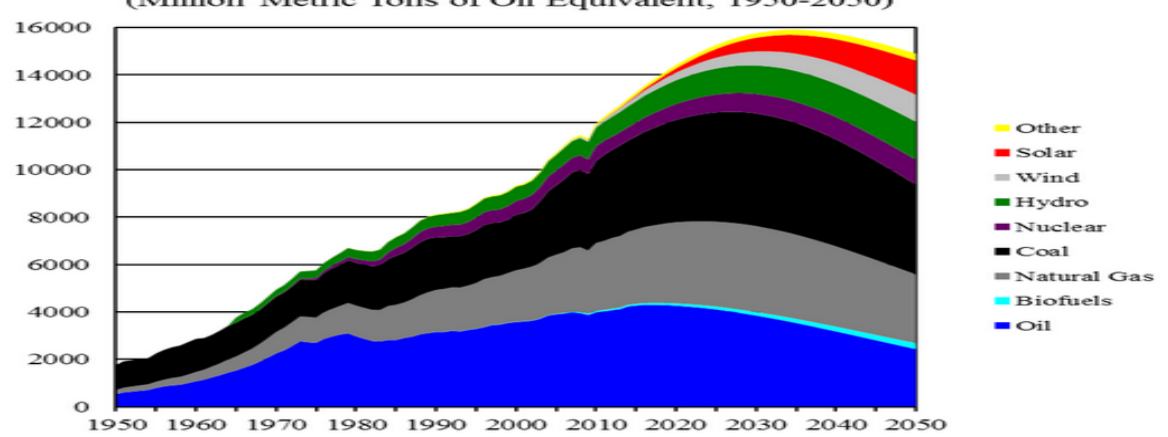

Figure 1: Increasing and decreasing trends of different energy sources from 1950-2050.

\begin{tabular}{|c|c|c|c|c|}
\hline Capacity, MWt & 2015 & 2010 & 2005 & 2000 \\
\hline Geothermal heat pumps & 50,258 & 33,134 & 15,384 & 5,275 \\
\hline Space heating & 7,602 & 5,394 & 4,366 & 3,263 \\
\hline Green house heating & 1,972 & 1,544 & 1,404 & 1,246 \\
\hline Aquaculture pond heating & 696 & 653 & 616 & 605 \\
\hline Agricultural drying & 161 & 125 & 157 & 74 \\
\hline Industrial uses & 614 & 533 & 484 & 474 \\
\hline Bathing and swimming & 9,143 & 6,700 & 5,401 & 3,957 \\
\hline Cooling/snow melting & 360 & 368 & 371 & 114 \\
\hline Others & 79 & 42 & 86 & 137 \\
\hline Total & 70,885 & 48,493 & 28,269 & 15,145 \\
\hline
\end{tabular}

Table 1: Summary of the various categories of direct-use worldwide for the period 2000-2015 [3].

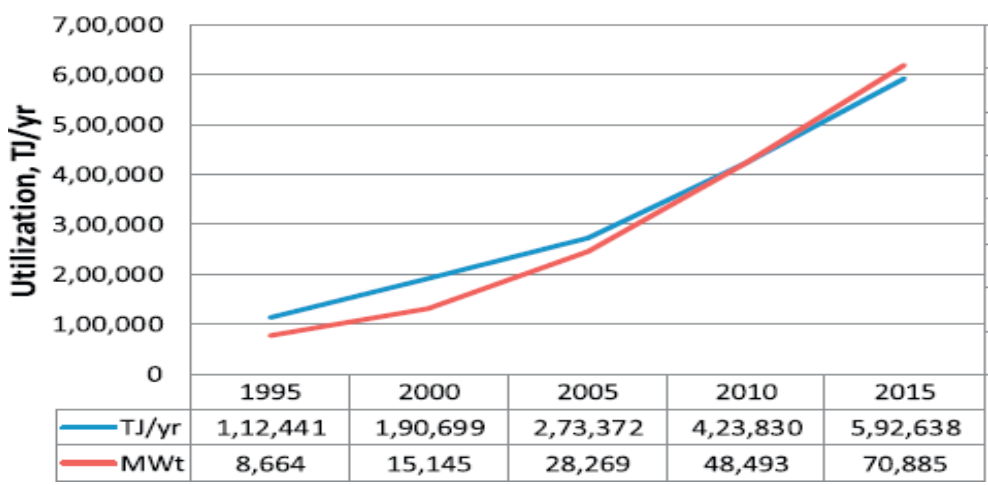

80,000

70,000

60,000

50,000

40,000

30,000

20,000

10,000

0

Figure 2a: The installed direct-use geothermal capacity and annual utilization from 1995 to 2015 [3]
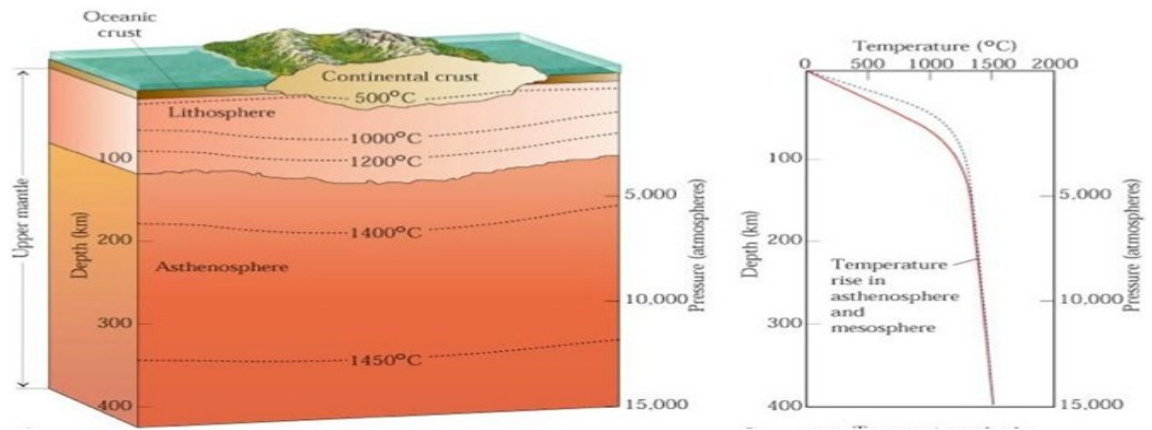

Figure 2b: Generalized interior of the earth showing increase of temperature with depth.

decay of radioactive isotopes and a portion is a relic of the planets structure about 4.5 billion years ago. Earth's heat flows from its interior toward the surface because it is a fact that heat flow from hotter to cooler region. Moreover, the tectonic processes further increase the 
distribution pattern of the geothermal energy regimes in the upper part of the Earth's crust.

The plate tectonic processes basis high temperatures sufficient to melt rock forming magma, which moves up toward the earth's crust and carries heat from below. Sometime magma rises to the surface through thin and fracture crust as lava. Generally, most magma remains below earth's surface and heat the surrounding rocks and subterranean water. Some of this water comes all the way up to the surface through faults and fractures in the earth as hot springs or geysers. When this rising hot water and steam is trapped in permeable rocks under a layer of impermeable rocks, it is called a geothermal reservoir. These reservoirs are sources of hydro geothermal energy that can potentially be tapped for electricity generation or direct use.

On the other hand, the hot dry rock geothermal resources are much deeper than hydrothermal resources. Hot dry rock energy comes from comparatively water-free hot rock found at a depth of about 4,000 meters or more under the Earth's surface (Figure $2 b$ ). One way is to extract energy by circulating water by man-made fractures in the hot rock. Heat can be extracted from the water at the surface for power generation, and the cool water can then be recycled through the fractures to pickup more heat, creating a closed-looped system.

Some preliminary studies have been carried out for the identification of hydro-geothermal sources in Pakistan [4], but no work is done to study the HDR source potentials in Pakistan. Current research study is first time being discussed here to identify the HDR geothermal energy potential in Pakistan (Figure 3).

\section{Hot dry rock geothermal energy potential in Pakistan}

The western border of the Indo-Pakistan continental plate inherent the past extensional tectonics resulting in rifted protocontinent and new oceanic crust formed during sea-floor spreading the eastern part of Pakistan, i.e., the region comprising mainly of Indus Plains, is characterized by a broad north-southtrnding sedimentary basin having thick Tertiary sequences underlain by Mesozoic and older rocks and overlain by Quaternary sediments (floodplain deposits of the Indus River) $[5,6]$. The southern Indus basin, the focal area of current study, is about $250 \mathrm{~km}$ broad and enclosed by the Thar Desert on the east and by the mountainous region of fold and thrust belts in Pakistan on the west. It had comparatively been tectonically stable during the Mesozoic, but the intensity of shallow Tertiary folding increases westward and become more pronounced in the strongly folded and faulted areas of the axial fold and thrust belt. The Indus River appears to more or less pursue the axis of basin.

The basement manifestations were only known as the "highs" of Jacobabad, Khairpur, Hyderabad, and others [5] and no plausible explanation could be established till early 1990s, largely owing to the lack of subsurface geological and geophysical information. Most of the earlier workers considered these highs as the result of subsurface northwest trending, narrow, fingers like extensions of Indian shield, known as "re-entrances" which caused deformation of the overlying geological strata [7].

But during early 1990s, a north-south trending southern Indus fossil-failed rift structure was identified, based on the detailed analysis of the archive aeromagnetic data (Figure 4a), buried beneath the thick piles of the Mesozoic and Cenozoic sediments in the southern Indus basin [6]. The depths of these inferred rift segments (i.e., the horsts and gerbens) were estimated as $+5 \mathrm{Km}$ for southern, $+9 \mathrm{Km}$ for central,

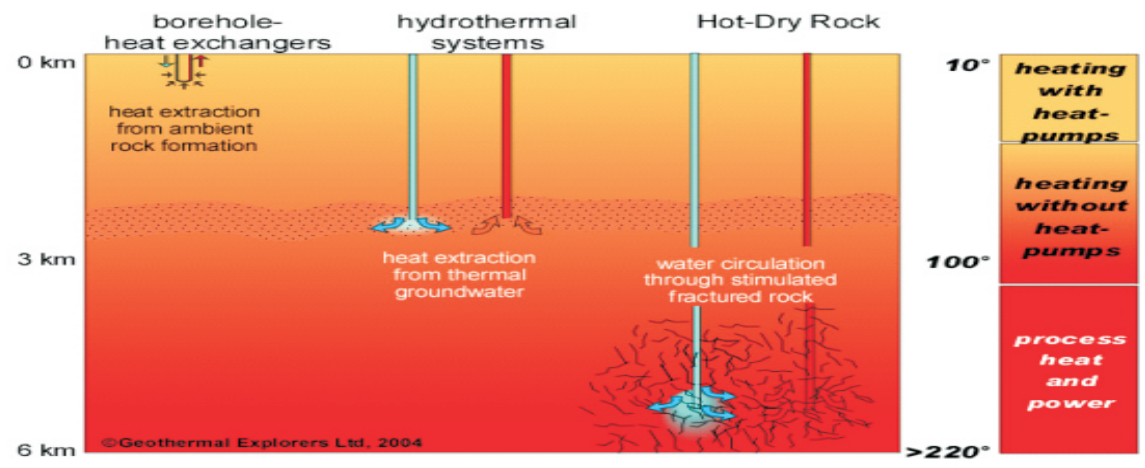

Figure 3: Schematic presentations showing different applicable extents of geothermal system in response to temperature and depth.

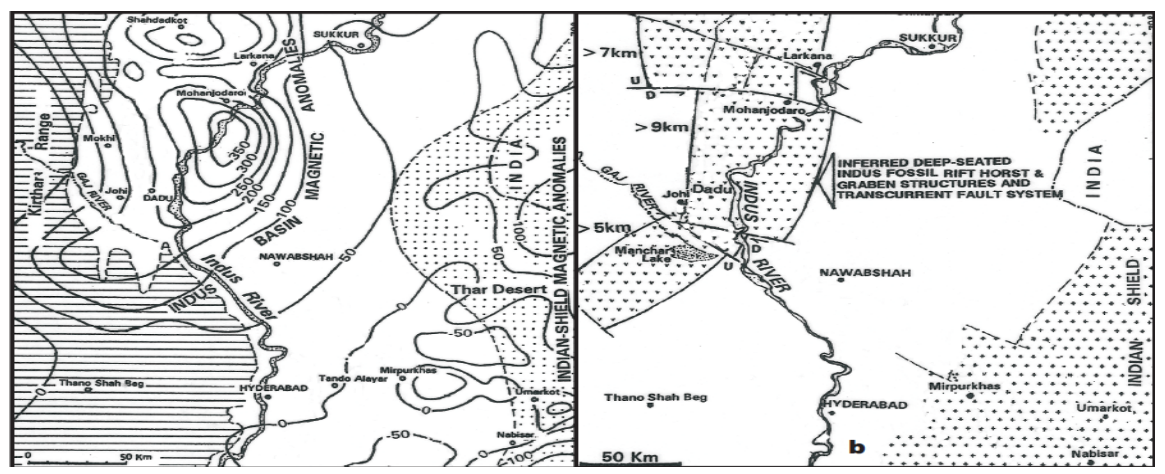

Figure 4: The southern Indus basin magnetic anomalies b) the inferred deep-seated fossil failed rift in the southern Indus basin [6]. 
and $+7 \mathrm{Km}$ for northern (Figure $4 \mathrm{~b}$ ). It was inferred that the vertical displacements of these horsts and grabens have affected the overlying sediments. These consequent gentle regional uplift-trends in the basin reflected as surface manifestations, which were used to call a Sibi, Jacobabad, Khairpur, Hyderabad and other "highs".

As evident from the fact that the rifting-tectonic environment encourages the high heat flow to the upper crust from the interior of the earth, the schematic tectonic model of southern Indus basin (Figure 5).

Shows the considerable prediction for the development of relatively higher geothermal anomalies within the basin. Similarly, in the southeast of the Indus Failed-Rift, another fossil-failed rift was also identified as Thar Rift based on the modeling of seismicity data [4]. These rift structures demonstrate admirable environments for the development of hydrocarbon source rocks, adequate heat for thermal maturity, and structures for seals and reservoirs in the southeastern region of Pakistan. The integrated investigations provided the valuable subsurface geological information and give confident for the hydrocarbon exploration activity in the Indus basin.

Since 1868 till july-2016, round about 1000 Oil \& Gas exploratory wells have been drilled down to depth ranging from +230 to +6400 in Pakistan [8]. Out of these wells more than 600 wells have been abandoned. In addition to these exploratory wells, 878 development wells have also been drilled. The total explored area of Pakistan is $827,268 \mathrm{~km}^{2}$. The drilling ratios between hydrocarbon discoveries and abundant wells remained as about 1:5 that shows for hydrocarbon exploration we lose five time of total investment. Satellite image of exploratory wells shows the exploration trend (Figure 6). Initially in the northern part of the Pakistan (Postwar plateau, Makran offshore regions, Suleiman range) drilling exploration started but in last four decades, many wells have been drilled in southern Indus basin. The data of these exploratory Oil and Gas wells will be an excellent and valuable research material for the estimation of Geothermal potential. In addition, the aeromagnetic studies have also exposed significant prediction for the HDR geothermal energy in Kharan-panjgur tectonic depression in western part of Pakistan [4]. It is anticipated that required HDR goal may come upon at much shallower depth.

\section{Pattern of Geothermal Gradient}

In the view of the multifaceted tectonic setup, huge variations are anticipated in the lateral and vertical geothermal gradient trend in Indus basin. From the data of borehole bottom temperatures, a preliminary attempt was made to develop a geothermal gradient anomaly map of part of the southern Indus basin [9], which has now been customized and updated. Satellite image (Figure 7) shows the spatial distribution pattern in relation to the surface tectonic setup around the southern Indus basin and the geothermal gradient anomalies have been overlaid on the mosaic of the image. In exposed geological trend of the eastern part of the Axial Fold-Thrust Belt the distribution of high geothermal gradient anomalies shows association. Conversely, the noticeable low thermal gradient anomaly shows a narrow elongation from Sibi area extending southward and changes its strike towards southeast passing through Larkana area across the upper part of the southern Indus basin in the direction of the Indian shield region. This zone of low gradient anomaly apparently divides the high gradient anomalies into northeastern and southwestern thermal gradient zones. The high gradient anomalies are inferred to be associated with faulted segments of the Indus fossil failed-rift.

The northeastern high geothermal gradient anomaly shows association with the southern part of the Suleiman syntaxes of the

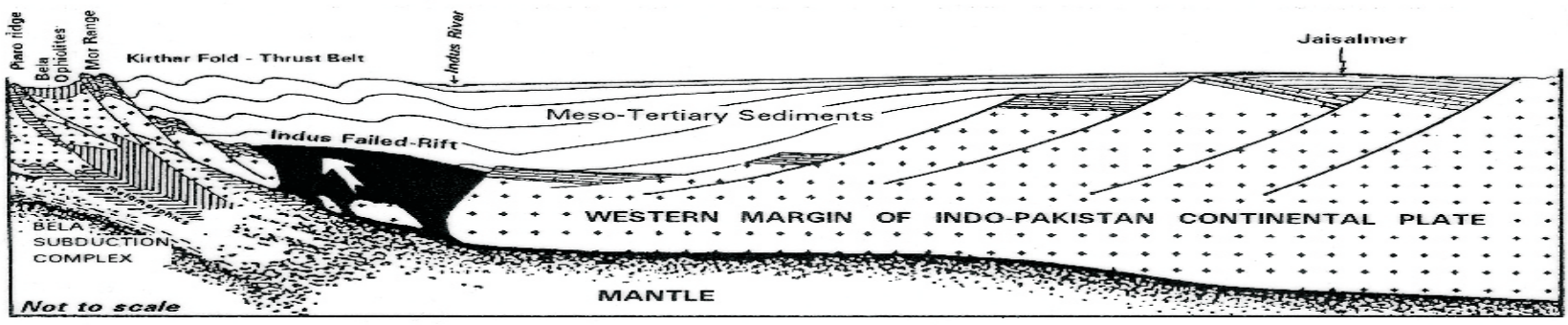

Figure 5: Schematic fossil-failed-rift model illustrates the resent-day tectonic setting in the southern Indus basin [4]

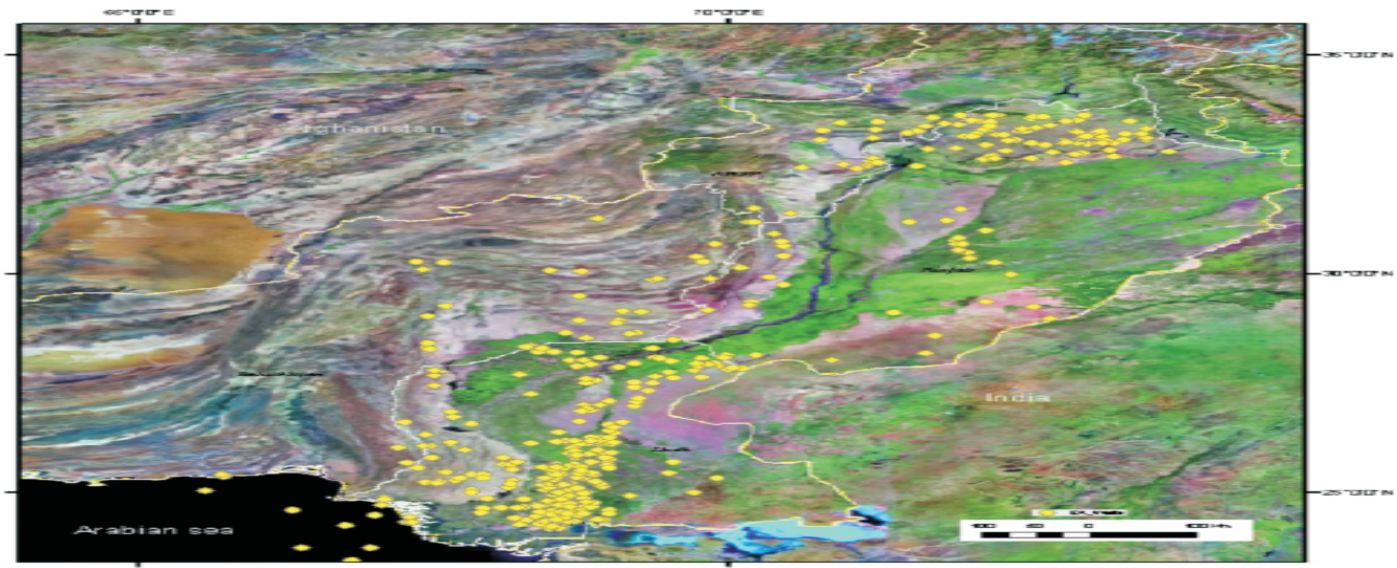

Figure 6: Solid circles show the location of Oil and gas exploratory drilled wells in Pakistan plotted on the map. 


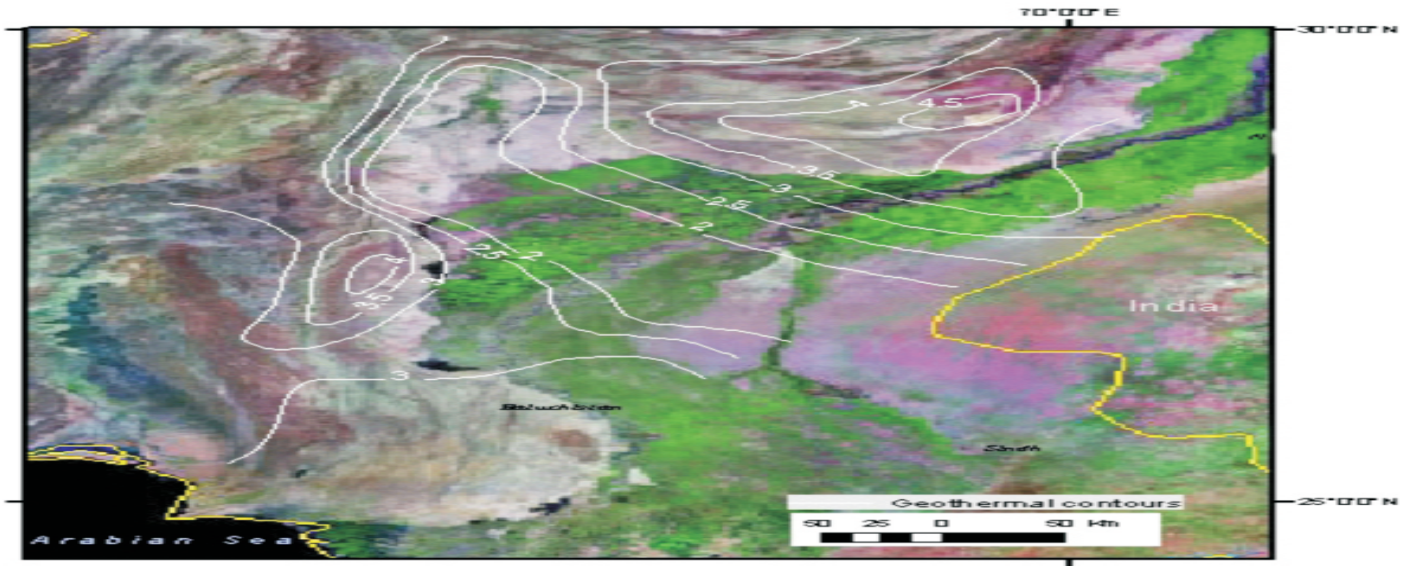

Figure 7: Overlay of isothermal gradient contours shows the anomalous distribution pattern with respect to Indus basin.

Axial-Fold-Thrust belt. In this region, the Giandari Oil and Gas well encountered an abnormally high geothermal gradient of $4.1^{\circ} \mathrm{C} / 100 \mathrm{~m}$ [9]. Similarly, in the south and southeast at Sui and Mari, the normal geothermal gradient was recorded ranging between 3.0 and $3.49^{\circ} \mathrm{C} / 100$ $\mathrm{m}$. Thermal spring is also recorded in this area [10].

High geothermal anomaly has been found over the eastern part of kirther range in south east of Khuzdar. This anomaly is generated due to deep-seated fossil failed-rift as revealed from schematic model presented in Figure 5. The isothermal gradient contour $(3.0 / 100 \mathrm{~m})$ between Uthal and Nawabshah indicates southward development of anomalous of high geothermal anomalies. Quadri and Shuaib reported that the thermal gradients increase from east $\left(2.36^{\circ} \mathrm{C} / 100 \mathrm{~m}\right)$ to west $\left(4.3^{\circ} \mathrm{C} / 100 \mathrm{~m}\right)$ in the Badin Hyderabad area $[11,12]$. It is inferred that the development of the high geothermal gradients in the southeastern areas is controlled by both the southern Indus and Thar rifting structures.

\section{Conclusion and Recommendations}

There is need to study the HDR resources to overcome the energy crises and for the commercial development of Pakistan. As discussed above the HDR resources are much deeper than the hydrothermal resources. Initially in the introductory phase of this technology development cost of well is high because of its depth. In case of Pakistan, subsurface information of exploratory Oil and Gas wells can be used and such cost can be saved. These exploratory \& development wells cover vast regions in the Indus Basin, poatwar plateau, Eastern flank of the Axial Fold-Thrust Belt, Coastal Zone of Arabian Sea. More than 600 exploratory wells have been abandoned, which roughly account for $70 \%$ cost of total investment of petroleum industry. The data of these wells laying in dead-record can play a vital role for the generation of electricity if the archive data, relevant to the purposed research study should be utilize then capital cost of HDR exploration project can be minimized. Thus, a substantial cost invested on the abandoned wells would be cashed back indirectly.

\section{References}

1. Beck MSF (2003) Geothermal energy for electric power: A REPP issue brief: In: Renewable Energy policy Project, Washington D.C., USA.

2. Zahoor SR (2008) Geothermal reservoirs: A renewable source of energy and an extension of petroleum engineering. SPE114718.

3. Lund JW, Boyd TL (2016) Direct utilization of geothermal energy 2015 worldwide reviews. Geothermics 60: 66-93.

4. Zaigham NA, Nayyer ZA (2007) Review of geothermal energy resources in Pakistan: J Renew Sustain Energy Rev.

5. Kazmi AH, Rana RA (1982) Tectonic map of Pakistan: Qetta: Geological Survey of Pakistan, Scale 1: 2,000,000,1.

6. Zaigham MA (1991) Bela ophiolites and associated mineralization in south part of axial-belt of Pakistan. Ph.D. thesis: University of Karachi, Pakistan.

7. Wadia DN (1931) The syntaxes of northwest Himalaya, its rocks, tectonic and orogeny. Geological Survey of India Records 65: 189-220.

8. HDIP (2008) Pakistan energy yearbook 2007: Basit A. Khan (compiler), Hydrocarbon Development Institute of Pakistan, Ministry of Petroleum \& Natural Resources, Islamabad, Pakistan.

9. Khan MA, Raze HA (1986) The role of geothermal gradient in hydrocarbon on Pakistan. J petrol Geol 9: 245-258.

10. Bakr MA (1965) Thermal springs of Pakistan: Geological Survey Pakistan Record. 16: 3-4.

11. Quadric VN, Shuaib M (1986) Hydrocarbon prospects of southern Indus basin AAPG Bulletin 70: 730-747.

12. Asif M (2009) Sustainable energy options for Pakistan. Renew Sustainable Energy Rev 13: 903-909. 